\title{
Drug selection in the treatment of breakthrough pain: how the pharmacokinetic profile of drugs is to be translated into clinical practice
}

\begin{abstract}
Breakthrough pain in cancer patients (BTP), also referred to as episodic or incident pain, occurs in a significant proportion of patients with baseline pain (40-60\%). It is characterized by rapid intensifying (within tens of seconds or a few minutes) and a strong intensity in the numerical rating scale always above 5 and a limited duration, usually up to about 60 minutes. The choice of the drug for the management of BTP in clinical practice should be based on a profound knowledge of pathophysiology of BTP and pharmacokinetic parameters of the drugs used.
\end{abstract}

Palliat Med Pract 2019; 13, 4: 211-215

Key words: breakthrough pain, treatment, drug pharmacokinetics.

\section{Introduction}

Breakthrough pain (BTP), also known as episodic or incident, occurs in a significant proportion (40-60\%) of cancer patients [1-4]. Two types of BTP were clinically distinguished: spontaneous (idiopathic), in which it is difficult to determine clearly identifiable causative factors, and incident, in which pain episodes are related to specific causative factors, dependent and independent of the patient. This ambiguity of the causative factors implies the division of incident pain into: volitional, which is caused by certain activities dependent on the patient, e.g. hygienic-care activities, change of position in bed, movement and non-volitional, which is caused by factors independent of the patient's will, e.g. coughing, sneezing, defecation. Spontaneous BTP amounts to approximately $39 \%$ of all BTP episodes, while incident constitutes approx. 44\%. Approx. 17\% of patients complain of mixed pain, i.e. a combination of idiopathic and incident pain. The maximum pain intensity on average is reached within approx. 3-15 minutes (range $<1-240$ minutes) for all BTP episodes. The average rate of increase in intensity is higher in incident pain than in spontaneous pain and amounts to 10 minutes and 20 minutes, respectively. The average duration of untreated BTP episodes is about 60 minutes (range $<1$ minute to 8 hours), whereas the median number of BTP episodes is 3 in a day (the range from 2 episodes in 7 days to 24 episodes in one day). The intensity of BTP usually oscillates around 7 on the numerical rating scale (NRS).

\footnotetext{
Address for correspondence:

Jarosław Woroń

Institute of Clinical Pharmacology, Department of Pharmacology,

Faculty of Medicine, Jagiellonian University, Collegium Medicum, Cracow,

Śniadeckich Str. 10, 31-531 Kraków

e-mail: farmakologiawpraktyce@woron.eu
}

Palliative Medicine in Practice 2019; 13, 4, 211-215

Copyright (C) Via Medica, ISSN 2545-0425

DOI: 10.5603/PMPI.2019.0021 
Knowledge of the BTP characteristics and the ability to differentiate its types based on causative factors plays an important role in the clinical practice as it allows to distinguish BTP from pain episodes that occur during the titration of an opioid dose used to treat chronic cancer pain $[5,6]$ and from end-ofdose pain. End-of-dose pain occurs in approximately $15-20 \%$ of patients and is directly attributable to the plasma half-life of the analgesic used to treat baseline pain, which implies appropriate intervals between successive drug doses [3]. It is important to be aware that a number of drugs and dietary supplements may interfere with the plasma half-life of analgesics used to treat baseline pain. Such a situation may involve, for example, morphine and oxycodone, which are mainly eliminated by kidneys. Both drugs are weak bases, which means in practice that loop diuretics, especially furosemide and urine acidifying drugs (vitamin C in large doses, cranberries) may significantly shorten the time of their analgesic effect [7-9]. In the case of end-of-dose pain, the dose of analgesic should be increased or intervals between subsequent administrations shortened.

Compared to patients with no diagnosis of BTP, patients with breakthrough pain are more likely to experience functional disorders, higher levels of anxiety and depression, and significantly worse quality of life. Moreover, in this group of patients the usage of hypnotics and other groups of psychotropic drugs increases, which in consequence may lead to a deterioration in the effectiveness of analgesic therapy and an increase in the risk of unfavourable drug interactions with analgesics [7-9].

Breakthrough pain management strategy should be based on an accurate diagnosis of the type of pain and its causes. The treatment of BTP episodes requires the administration of additional analgesics, which have an optimal pharmacokinetic profile for different types of BTP [8]. Otherwise, the treatment of BTP will be ineffective, with an increased risk of side effects or of addiction. Additional difficulty in choosing the right drug results from the fact that different types of BTP may occur alternately in one patient, therefore the choice of treatment should be based not only on the analysis of one characteristic of BTP, e.g. the speed of increase of pain intensity, but also on the possible duration and number of episodes per day and their frequency in the longer term, e.g. within 7 days.

\section{How to translate drug pharmacokinetics into clinical practice?}

In the choice of treatment, considering the characteristics of BTP and especially its intensity, "strong" opioid analgesics should be favoured. In Polish medicine, one of the most commonly used drugs is morphine administered orally in the form of immediate release (IR) tablets, much less frequently in the form of an aqueous solution. The disadvantage of this route of morphine use is low bioavailability, significant "first pass" effect and delayed onset of action that occurs approximately 30-40 minutes after administration, which, with respect to BTP characteristics, significantly decrease the effectiveness of treatment of various types of breakthrough pain. From a practical point of view, "oral" morphine can be effective in treating volitional incident pain. Then, being aware of the approaching pain-inducing activity, the patient should receive in advance a short-acting morphine via oral route. However, it is necessary to add that administering anticipation drug is associated with the risk of "unnecessary opioid use", as not always the expected stimulus will cause BTP.

The analgesic efficacy of morphine IR products administered via oral route during the first $30 \mathrm{~min}$ utes after administration is the same as the placebo effect. Therefore, in most patients with BTP, especially in episodes of unpredictable onset and duration, the "pseudo analgesic" effect of short-acting morphine, which may be more related to spontaneous pain relief than to the morphine analgesic effect, can be described as the "pseudo analgesic" effect.

In hospitalized patients, additional doses of morphine may be administered by the intravenous route, which is characterized by a rapid onset of analgesic action (approximately 5-8 minutes), in the case of BTP. However, the intravenous route is difficult to be administered in patients staying at home and often involved in normal routine activities. The plasma half-life of morphine reduces the effectiveness of a single dose for BTP episodes with the incidence of more than 4 hours during the day. In addition, factors such as difficulties in swallowing, nausea and vomiting may limit or prevent the oral route of administration. IR morphine should also be considered in the case of side effects caused by opioids used to treat baseline pain. An additional dose of morphine may significantly intensify opioid-induced constipation.

In most types of BTP, intranasal, sublingual or buccal fentanyl products are an effective alternative to IR "oral" morphine [1-3]. In clinical practice, it is important to remember about differences in pharmacokinetic parameters of individual products and factors influencing the route of drug administration, which allows to choose an effective therapy adjusted to individual needs and preferences of the patient $[1-3,8,9]$.

Figure 1 shows the pharmacokinetics of various fentanyl products used in the treatment of BTP. 


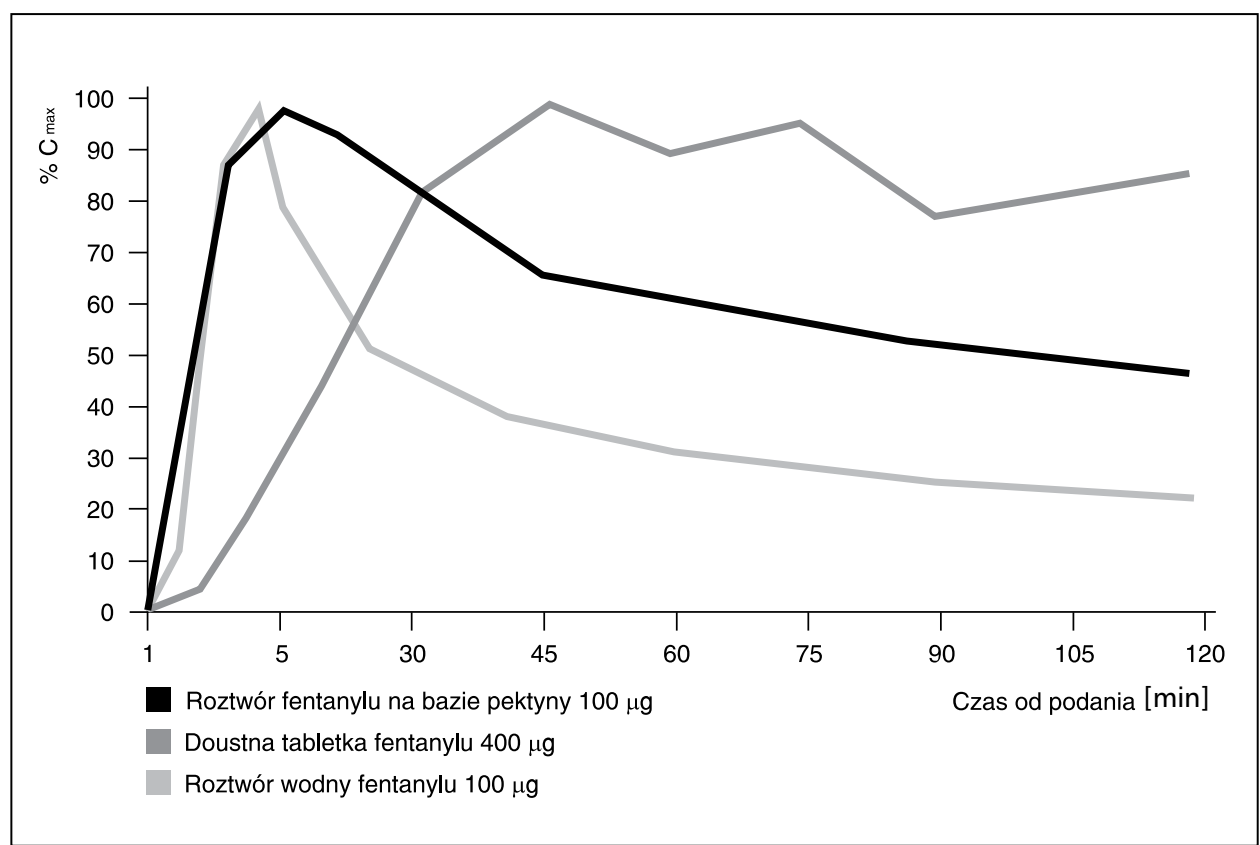

Figure 1. Pharmacokinetics of fentanyl products used for the breakthrough pain treatment

Table 1. Pharmacokinetic parameters of fentanyl-containing medicinal products in the treatment of breakthrough pain

\begin{tabular}{|c|c|c|c|c|}
\hline $\begin{array}{l}\text { Pharmacokinetic } \\
\text { parameter }\end{array}$ & $\begin{array}{c}\text { Instanyl } \\
\text { Fentanyl nasal } \\
\text { spray }\end{array}$ & $\begin{array}{c}\text { PecFent } \\
\text { Fentanyl pectin based } \\
\text { fentanyl nasal spray }\end{array}$ & $\begin{array}{c}\text { Vellofent } \\
\text { Fentanyl sublingual } \\
\text { tablet }\end{array}$ & $\begin{array}{c}\text { Effentora } \\
\text { Fentanyl buccal } \\
\text { tablet }\end{array}$ \\
\hline Route of administration & Intranasal & Intranasal & Sublingual & Buccal \\
\hline $\begin{array}{l}\text { Bioavailability from the ad- } \\
\text { ministration site }\end{array}$ & $89 \%$ & $60 \%$ & $70 \%$ & $65 \%$ \\
\hline $\begin{array}{l}\text { The time to reach the max- } \\
\text { imum serum concentration } \\
\text { expressed in minutes }\left(T_{\max }\right)\end{array}$ & $9-15$ & $15-21$ & 50 & 47 \\
\hline $\begin{array}{l}\text { The onset of analgesic effect, } \\
\text { relative latency expressed in } \\
\text { minutes }\end{array}$ & 5 & 5 & 10 & 15 \\
\hline $\begin{array}{l}\text { Plasma half-life expressed in } \\
\text { hours }\end{array}$ & $3-4$ & $15-25$ & 12 & 22 \\
\hline
\end{tabular}

Considering the BTP characteristics, $\mathrm{T}_{\max }$, i.e. the rate at which the peak concentration of the drug in the central compartment $\left(C_{\max }\right)$ is reached, is crucial when selecting a drug. This applies especially to incident, non-volitional and spontaneous BTP with a rapid intensifying and severe intensity. Considering the duration of single BTP episodes, an appropriate plasma half-life is essential to ensure effective analgesia of both short (up to 60 minutes) and longer BTP episodes. The plasma half-life also plays an important role in the incidence of several BTP episodes per day, especially when the interval between subsequent pain attacks is several hours. In such cases, a relatively long plasma half-life may allow the patient to limit the administration of the next opioid dose.

Reducing the need for further doses plays an important role in minimising the risk of developing a potential addiction. A quick time needed to reach $C_{\max }$ guarantees a rapid onset of action, but it is also a factor increasing the risk of addiction. This effect is additionally intensified in the case of a rapid decrease in $C_{\max }$, which may result in a shorter therapeutic effect below the duration of a single BTP episode or a series of several subsequent episodes. This can lead to a situation where the patient takes an extra dose of the drug without the required interval between doses. Re- 
peated, rapid change of $C_{\text {max }}$ is an additional important factor contributing to the occurrence of addiction.

Improper drug administration by the patient may also increase the risk of addiction in the case of long $\mathrm{T}_{\max }$, which is inadequate to the period of pain intensifying during BTP episode. In such situations, the patient, trying to "improve" the analgesic effect, administer the next dose of the drug and in consequence increases $C_{\max }$ above the "titrated" therapeutic concentration of the drug. An increase in opioid concentration inadequate to the requirement resulting from breakthrough pain episodes may also occur if a part of fentanyl contained in transmucosal products is swallowed. Absorption from the gastrointestinal tract is related to the "first pass" effect, which can cause unpredictable opioid concentration increase in relation to the concentration obtained via the transmucosal route. Due to the different formulations of fentanyl for the treatment of BTP, factors directly influencing the possible routes of administration should also be taken into account in the choice of the optimal therapy. Xerostomia occurs in $78-82 \%$ of cancer patients,

\section{Table 2. Characteristics of breakthrough pain and drug selection}

\begin{tabular}{|c|c|}
\hline $\begin{array}{l}\text { Drug used to } \\
\text { treat break- } \\
\text { through pain }\end{array}$ & How pharmacokinetics affects the selection in clinical practice \\
\hline Instanyl & $\begin{array}{l}\text { Due to the drug form there is no release process and rapid absorption occurs. Furthermore, the dis- } \\
\text { tribution of fentanyl to the central nervous system (CNS) is achieved not only through the absorption } \\
\text { of the drug into the central compartment (circulatory system), but also through the direct distribution } \\
\text { of the drug to the CNS through the structures of vascular plexuses and the nervous system structure. } \\
\text { Therefore, it is an effective solution in a situation where the intensity of BTP increases rapidly. After } \\
\text { intranasal administration, the drug is highly bioavailable and has a rapid onset of analgesia (approx. } \\
5 \text { minutes). A very short duration of action (less than } 1 \text { hour) limits the use of the drug in longer BTP } \\
\text { episodes or in the case of several subsequent episodes at short intervals. Rapid increase and decrease } \\
\text { in the peak plasma concentration }\left(C_{\text {max }} \text { ) may increase the risk of addiction, especially in BTP episodes }\right. \\
\text { that more slowly intensifying or of longer duration than the drug period of analgesic action, when } \\
\text { the patient takes the drug incorrectly }\end{array}$ \\
\hline PecFent & $\begin{array}{l}\text { Intranasal pectin based fentanyl spray. After administration of the drug, pectin and calcium ions } \\
\text { present in the nasal mucosa interact with each other, resulting in the formation of a gel that keeps } \\
\text { fentanyl at the administration site, preventing the drug dripping down the throat and swallowing. } \\
\text { Pectin gel ensures fast } T_{\max } \text { which translates into a rapid onset of analgesia ( } 5 \text { minutes) and extends } \\
\text { the time of absorption of the entire dose of fentanyl, which translates into a longer stabilization of } \\
\mathrm{C}_{\max } \text { at the therapeutic level so that there are no quick fluctuations in the fentanyl concentration in } \\
\text { time. A quick analgesic effect allows PecFent to be used in rapidly intensifying BTP. Stable } \mathrm{C}_{\max } \text { at the } \\
\text { therapeutic level for approx. } 90 \text { minutes ensures the effectiveness of the drug also in the treatment } \\
\text { of longer pain episodes or several short episodes separated by a time interval. A rapid onset of ac- } \\
\text { tion, stable } C_{\max } \text { at the therapeutic level and a long half-life increase the effectiveness of the drug in } \\
\text { different BTP types, thus reducing the risk of misuse and abuse of the drug, and, consequently the } \\
\text { development of addiction. Additionally, pectin gel prevents the absorption of subsequent fentanyl } \\
\text { doses administered contrary to the SPC, which also significantly reduces the risk of addiction. From } \\
\text { a pharmacokinetic point of view, it appears that a pectin-based fentanyl nasal spray is a universal } \\
\text { choice for the treatment of most BTP types }\end{array}$ \\
\hline Vellofent & $\begin{array}{l}\text { The drug is in the form of a tablet administered sublingually. After application, the tablet dissolves } \\
\text { for approx. } 25 \text { minutes. The release of fentanyl from the tablet may be impaired in xerostomia, oral } \\
\text { mucositis and the use of peripheral anticholinergic drugs. Approx. } 50 \% \text { of the drug is swallowed and } \\
\text { absorbed from the gastrointestinal (GI) tract. The drug is characterized by a long } \mathrm{T}_{\max } \text { and moderate } \\
\text { plasma half-life. Due to the heterogeneous and time-dependent absorption, an unpredictable increase } \\
\text { in concentration, inadequate to the duration of the BTP episode, is likely to occur. Pharmacokinetic } \\
\text { properties allow the drug to be used in the treatment of pain with moderate time of exacerbation } \\
\text { and longer duration }\end{array}$ \\
\hline Effentora & $\begin{array}{l}\text { The drug may be administered either by buccal or sublingual route. In the first phase after adminis- } \\
\text { tration citric acid and } \mathrm{CO}_{2} \text { are released from the tablet, which results in acidification of the oral cavity } \\
\text { environment. Lower } \mathrm{pH} \text { contributes to ionization and dissolution of fentanyl from the tablet. Over the } \\
\text { course of time, } \mathrm{CO}_{2} \text { is eliminated, resulting in a pH increase. As a result, dissolved fentanyl becomes } \\
\text { non-ionized and can be absorbed by the mucous membrane. The complex process of releasing and } \\
\text { absorbing fentanyl from the tablet translates into a slower time to reach } \mathrm{C}_{\text {max }} \text { Only approx. } 50 \% \\
\text { of the fentanyl contained in the tablet is absorbed through the oral mucosa, the remaining part is } \\
\text { swallowed and slowly absorbed from the Gl tract subject to the first pass effect, which may cause } \\
\text { unpredictable concentration fluctuations over time after administration of the tablet. The drug is } \\
\text { characterized by a long period of reaching the maximum serum concentration and a long plasma } \\
\text { half-life, which implies its choice in the treatment of slowly intensifying and long duration of BTP }\end{array}$ \\
\hline
\end{tabular}


Table 3. Clinical criteria for selecting fentanyl products for breakthrough pain management

\begin{tabular}{ll} 
Characteristics of breakthrough pain episode & Proposed drug selection \\
$\begin{array}{l}\text { Very short time of intensifying pain and short duration of } \\
\text { breakthrough pain episode }\end{array}$ & $\begin{array}{l}\text { Intranasal fentanyl spray or intranasal pectin based } \\
\text { fentanyl spray }\end{array}$ \\
$\begin{array}{l}\text { Short time of intensifying pain and longer duration of } \\
\text { breakthrough pain episode }\end{array}$ & $\begin{array}{l}\text { Intranasal pectin based fentanyl spray, } \\
\text { "sublingual" fentanyl }\end{array}$ \\
$\begin{array}{l}\text { Slow time of intensifying pain and prolonged duration of } \\
\text { breakthrough pain episode }\end{array}$ & $\begin{array}{l}\text { Intranasal pectin based fentanyl spray, } \\
\text { "sublingual" or "buccal" fentanyl }\end{array}$ \\
\hline
\end{tabular}

salivary glands hypofunction in $82-83 \%$ of patients and oral mucositis in $20-40 \%$ of chemotherapy patients may prevent the choice of sublingual or buccal route. Epistaxis, on the other hand, may affect the absorption from intranasal solutions.

Table 1 presents pharmacokinetic parameters of individual fentanyl-containing drugs available on the Polish market.

From a practical point of view, not only the onset of action, but also the stability of the drug concentration in the steady-state and the plasma half-life are important for the selection of analgesic suitable for the BTP characterization [1, 2, 7-9]. A common mistake is the use of sublingual buprenorphine in the treatment of BTP. The ineffectiveness of this form of drug is related to the time after which it reaches peak plasma concentration $\left(C_{\max }\right)$. This parameter significantly determines the onset of analgesia, and for sublingual buprenorphine it is 90 minutes. The overall analgesic effect is determined by the total exposure to the drug, which is understood as the area under the plasma drug concentration-time curve. Table 2 summarises information that helps to select the right drug according to the characteristics of BTP.

Table 3 presents the suggestions for the use of different rapid-acting fentanyl products, based on the characteristics of breakthrough pain.

\section{Summary}

The selection of a drug for the treatment of BTP should be individualized. Knowledge of the PK/PD profile allows for optimal selection of an effective and safe medical product [1, 2, 9]. It should be emphasized that fentanyl used to treat BTP can be combined with other opioids, including buprenorphine, whose until reaching "ceiling analgesic" dose (approximately
$15 \mathrm{mg} /$ day, in clinical practice doses up to $3 \mathrm{mg} /$ day are used) acts similarly to other opioid analgesics as a pure agonist at $\mu$-opioid receptors. However, the use of fentanyl in combination with nalbuphine is not recommended $[1,2,5,8,9]$. Since BTP may be characterized by a different pathophysiology than baseline pain, in clinical practice the dose of the opioid used to treat BTP rather does not represent the appropriate fraction (percentage) of the dose used to treat baseline pain. The complexity of the phenomena that lead to the occurrence of a BTP episode rather precludes such simple calculations. Therefore, a thorough clinical assessment of pain in the context of other patient symptoms, as well as psychological, social and spiritual circumstances remains essential [2-5].

\section{References}

1. Dobrogowski J, Wordliczek J. Leczenie bólu. Wydawnictwo Lekarskie PZWL, Warszawa 2017.

2. Malec-Milewska M, Woroń J. Kompendium leczenia bólu. Medical Education, Warszawa 2017.

3. Hanna M, Żylicz Z. Cancer Pain. Springer, New York 2014.

4. Novotna S, Valentova K, Fricova J, et al. ETHYFYL Study Group. A randomized, placebo-controlled study of a new sublingual formulation of fentanyl citrate (fentanyl ethypharm) for breakthrough pain in opioid-treated patients with cancer. Clin Ther. 2014; 36(3): 357-367, doi: 10.1016/j.clinthera.2014.01.006, indexed in Pubmed: 24508417.

5. Woroń J. Chory na nowotwór. Interakcje analgetyków i leków stosowanych w terapii objawów współtowarzyszących. Medical Education, Warszawa 2019.

6. Chisholm-Burns MA, Schwinghammer TL, Malone PM. Pharmacotherapy Principles \& Practice. Mc Graw Hill Education, New York 2019.

7. Rosenthal LD, Burchum JR. Pharmacotherapeutics for Advances Practice Providers. Elsevier, St. Louis 2018.

8. DiPiro JT, Talbert LR, Yee GC. Pharmacotherapy, a Pathophysiologic Approach. Mc Graw Hill Education, New York 2017.

9. Wirfs MJ. Prescribing Drug Therapy. Springer Publishing Company, New York 2019. 


\section{Wybór leku w terapii bólu przebijającego, czyli jak przekładać profil farmakokinetyczny leków na praktykę kliniczną}

Artykuł jest tłumaczeniem pracy: Woroń J., The choice of the drug in the therapy of breakthrough pain, or how to translate the pharmacokinetic profile of drugs into clinical practice. Palliat. Med. Pract. 2019 tom 13, nr 4: 211-215.

Należy cytować wersję pierwotną.

Piśmiennictwo znajduje się na stronie 215.

\section{Streszczenie}

Ból przebijający (BTP), nazywany także epizodycznym bądź incydentalnym, występuje u znacznego odsetka chorych na nowotwory (40-60\%). Ból przebijający u chorych na nowotwory cechuje szybki wzrost (w okresie kilkudziesięciu sekund bądź kilku minut) i znaczne natężenie w skali numerycznej zawsze powyżej 5 oraz ograniczony czas trwania, najczęściej do około 60 minut. Wybór leku w praktyce klinicznej powinien być oparty na dokładnej znajomości patomechanizmu bólu przebijającego i parametrów farmakokinetycznych stosowanych leków.

Palliat Med Pract 2019; 13, 4: 216-220

Słowa kluczowe: ból przebijający, leczenie, farmakokinetyka leków

\section{Wstęp}

Ból przebijający (BTP, breakthrough pain), nazywany także epizodycznym bądź incydentalnym, występuje u znacznego odsetka (40-60\%) chorych na nowotwory [1-4]. Klinicznie wyróżniono dwa rodzaje BTP: spontaniczny, w którym trudno wskazać jasno identyfikowalne czynniki wywołujące, i incydentalny, w którym epizody bólowe związane są ze sprecyzowanymi czynnikami wywołującymi, zależnymi i niezależnymi od pacjenta. Ta dwojakość czynników wywołujących implikuje podział bólu incydentalnego na: dobrowolny, który wywołany jest przez określone aktywności zależne od pacjenta, na przykład czynności higieniczne, zmiana pozycji w łóżku, ruch, i niedobrowolny, który wywołany jest przez czynniki niezależne od woli pacjenta, na przykład kaszel, kichnięcie, defekację. Ból przebijający spontaniczny stanowi około 39\% wszystkich epizodów BTP, natomiast incydentalny około $44 \%$. U około $17 \%$ chorych występuje ból mieszany, czyli połączenie bólu samoistnego i incydentalnego. Maksymalne natężenie bólu narasta średnio przez około 3-15 minut (zakres < 1-240 min) dla wszystkich epizodów BTP. Średnie tempo narastania jest szybsze w bólu incydentalnym niż w bólu spontanicznym i wynosi, odpowiednio 10 minut i 20 minut.

\section{Adres do korespondencji:}

Jarosław Woroń

Zakład Farmakologii Klinicznej, Katedry Farmakologii, Wydział Lekarski,

Uniwersytet Jagielloński, Collegium Medicum, Kraków,

ul. Śniadeckich 10, 31-531 Kraków

e-mail: farmakologiawpraktyce@woron.eu 
Średni czasu trwania nieleczonych epizodów BTP wynosi około 60 minut (zakres $<1$ min do 8 godz.). Natomiast mediana liczby epizodów bólu przebijającego wynosi 3 na dobę (zakres 2 na 7 dni do 24/dobę). Natężenie bólu przebijającego z reguły oscyluje wokół $7 \mathrm{w}$ skali numerycznej (NRS, numerical rating scale).

Znajomość cech charakterystycznych dla BTP i umiejętność różnicowania jego rodzajów, na podstawie czynników wywołujących, odgrywa istotną rolę w klinice, bowiem pozwala na odróżnienie BTP od epizodów bólu, które pojawiają się podczas miareczkowania dawki opioidu stosowanego do leczenia przewlekłego bólu nowotworowego $[5,6]$ i od bólu końca dawki. Ból końca dawki występuje u około 15-20\% pacjentów i wynika bezpośrednio z okresu półtrwania analgetyku zastosowanego w leczeniu bólu podstawowego, który implikuje odpowiednie odstępy czasowe pomiędzy kolejnymi dawkami leku [3]. Należy mieć świadomość, że wiele leków i suplementów diety może zaburzać okres półtrwania analgetyków stosowanych w leczeniu bólu podstawowego. Taka sytuacja może dotyczyć na przykład morfiny i oksykodonu, które eliminowane są głównie przez nerki. Obydwa leki są słabymi zasadami, co powoduje w praktyce, że diuretyki pętlowe, zwłaszcza furosemid, i leki zakwaszające mocz (witamina $\mathrm{C}$ w dużych dawkach, żurawina) mogą znacznie skracać czas ich działania przeciwbólowego [7-9]. W przypadku wystąpienia bólu końca dawki należy zwiększyć dawkę analgetyku lub skrócić odstępy czasowe pomiędzy kolejnymi podaniami leku.

W porównaniu z pacjentami, u których nie stwierdzono BTP, chorzy z rozpoznaniem bólu przebijającego częściej wykazują zaburzenia funkcjonowania, wyższy poziom lęku i depresji oraz znacznie gorszą jakość życia. Co więcej, w tej grupie pacjentów zwiększeniu ulega zużycie leków nasennych i innych grup leków psychotropowych, co w konsekwencji może doprowadzić do pogorszenia skuteczności terapii przeciwbólowej i wzrost ryzyka występowania niekorzystnych interakcji z analgetykami [7-9].

Strategia postępowania w BTP powinna opierać się na dokładnym rozpoznaniu rodzaju bólu i jego przyczyn. Leczenie epizodów bólu przebijającego wymaga zastosowania dodatkowych analgetyków, które charakteryzuje optymalny profil farmakokinetyczny w odniesieniu do różnych rodzajów BTP [8]. W przeciwnym razie leczenie bólu przebijającego będzie nieskuteczne, przy zwiększonym ryzyku wystąpienia działań niepożądanych lub zwiększonym ryzykiem uzależnienia. Dodatkowa trudność w doborze odpowiedniego leku wynika z faktu, że różne rodzaje BTP mogą występować naprzemiennie u jednego pacjenta, dlatego wybór leczenia powinien opierać się nie tylko na analizie jednej cechy BTP, na przykład szybkości narastania epizodu bólowego, ale także obejmować możliwy czas trwania i liczbę epizodów w okresie doby i ich częstotliwość w dłuższej perspektywie czasowej, na przykład $7 \mathrm{dni}$.

\section{Jak farmakokinetykę leków przełożyć na praktykę kliniczną}

Mając na względzie cechy BTP, a zwłaszcza jego natężenie, w wyborze leczenia należy preferować "silne" analgetyki opioidowe. W warunkach polskich jednym z najczęściej stosowanych leków jest morfina podawana drogą doustną $w$ postaci tabletek o natychmiastowym uwalnianiu, znacznie rzadziej w postaci roztworu wodnego. Wadą tej drogi stosowania morfiny jest niska biodostępność, znaczny efekt pierwszego przejścia i długi początek działania, który występuje dopiero po 30-40 minutach od podania, co w odniesieniu do charakterystyki BTP istotnie ogranicza skuteczność leczenia różnych rodzajów bólu przebijającego. Z praktycznego punktu widzenia "doustna" morfina może być skuteczna w leczeniu bólów incydentalnych dobrowolnych. Wówczas pacjent mając świadomość zbliżającej się aktywności wywołującej ból, powinien z odpowiednim wyprzedzeniem otrzymać szybkodziałającą morfinę drogą doustną. Należy jednak dodać, że podanie leku mające na celu wyprzedzenie bólu jest związane z ryzykiem przyjęcia „opioidu bez potrzeby", ponieważ nie zawsze spodziewany bodziec będzie wywoływał BTP.

Skuteczność przeciwbólowa produktów morfiny o natychmiastowym uwalnianiu stosowanych drogą doustną w pierwszych 30 minutach od podania jest tożsama $z$ efektem placebo, dlatego u większości chorych z BTP, zwłaszcza w epizodach o nieprzewidywalnym początku i czasie trwania, można mówić o „pseudo analgetycznym” efekcie działania szybkodziałającej morfiny, który może być bardziej związany z samoistnym ustąpieniem bólu niż z efektem analgetycznym.

U pacjentów hospitalizowanych, w przypadku wystąpienia bólu przebijającego można podawać dodatkowe dawki morfiny drogą dożylną, którą cechuje szybki początek działania przeciwbólowego (ok. 5-8 min). Jednak droga dożylna jest trudna do zastosowania u pacjentów przebywających w domu i nierzadko prowadzących normalną aktywność. Okres półtrwania morfiny zmniejsza skuteczność pojedynczej dawki w przypadku epizodów bólu przebijającego o częstotliwości występowania powyżej 4 godzin w ciągu dnia. Także takie czynniki, jak utrudnione połykanie, nudności i wymioty mogą ograniczać lub uniemożliwić doustną drogę podania 
leku. Należy rozważyć zastosowanie szybkodziałającej morfiny także w przypadku działań niepożadanych wywołanych przez opioidy stosowane w leczeniu bólu podstawowego. Dodatkowa dawka morfiny może bardzo znacznie nasilać występowanie zaparć po-opioidowych.

W większości rodzajów BTP skuteczną alternatywą dla "doustnej” szybkodziałającej morfiny stanowią produkty fentanylu podawane drogą donosową, podjęzykową lub podpoliczkową [1-3]. W praktyce klinicznej istotne jest, aby pamiętać o różnicach parametrów farmakokinetycznych poszczególnych produktów i czynnikach wpływających na drogę podania leku, co pozwala na wybór skutecznej terapii dostosowanej do indywidualnych potrzeb i preferencji pacjenta $[1-3,8,9]$.

Na rycinie 1 przedstawiono farmakokinetykę różnych produktów fentanylu stosowanych w leczeniu BTP. Mając na uwagę cechy BTP bardzo istotny w wyborze leku jest $\mathrm{T}_{\max }$, czyli szybkość osiągnięcia maksymalnego stężenia leku w kompartmencie centralnym $\left(C_{\max }\right)$. Dotyczy to zwłaszcza bólów przebijających incydentalnych niedobrowolnych i spontanicznych o szybkim czasie narastania i silnym natężeniu. Mając na względzie czas trwania pojedynczych epizodów BTP, istotny jest odpowiedni okres półtrwania,

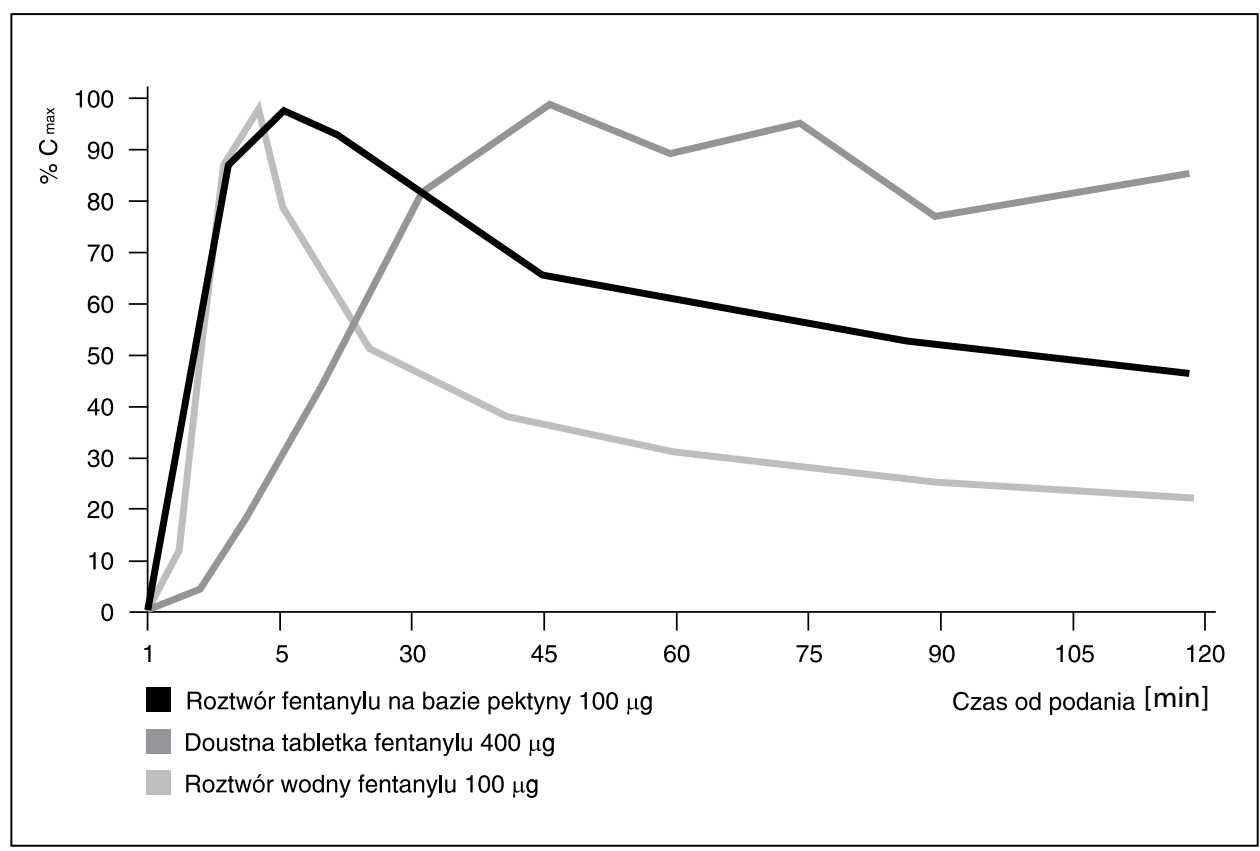

Rycina 1. Farmakokinetyka preparatów fentanylu stosowanego w terapii bólu przebijającego

Tabela 1. Parametry farmakokinetyczne produktów leczniczych zawierających fentanyl przeznaczonych do stosowania w leczeniu bólu przebijającego

\begin{tabular}{|c|c|c|c|c|}
\hline $\begin{array}{l}\text { Parametr } \\
\text { farmakokinetyczny }\end{array}$ & $\begin{array}{l}\text { Instanyl } \\
\text { Roztwór wodny } \\
\text { fentanylu }\end{array}$ & $\begin{array}{c}\text { PecFent } \\
\text { Roztwór fentanylu } \\
\text { na bazie pektyny }\end{array}$ & $\begin{array}{c}\text { Vellofent } \\
\text { Tabletka fentanylu }\end{array}$ & $\begin{array}{c}\text { Effentora } \\
\text { Tabletka fentanylu }\end{array}$ \\
\hline Droga podania & Donosowa & Donosowa & Podjęzykowa & Podpoliczkowa \\
\hline $\begin{array}{l}\text { Biodostępność z miejsca } \\
\text { podania }\end{array}$ & $89 \%$ & $60 \%$ & $70 \%$ & $65 \%$ \\
\hline $\begin{array}{l}\text { Czas osiągnięcia maksymal- } \\
\text { nego stężenia w surowicy } \\
\text { wyrażony w minutach }\left(T_{\max }\right)\end{array}$ & $9-15$ & $15-21$ & 50 & 47 \\
\hline $\begin{array}{l}\text { Początek efektu przeciw- } \\
\text { bólowego, względny czas } \\
\text { latencji wyrażony w minu- } \\
\text { tach }\end{array}$ & 5 & 5 & 10 & 15 \\
\hline $\begin{array}{l}\text { Okres półtrwania wyrażo- } \\
\text { ny w godzinach }\end{array}$ & $3-4$ & $15-25$ & 12 & 22 \\
\hline
\end{tabular}


Tabela 2. Charakterystyka bólu przebijającego a wybór leku

\begin{tabular}{|c|c|}
\hline $\begin{array}{l}\text { Lek stosowany } \\
\text { w leczeniu bólu } \\
\text { przebijającego }\end{array}$ & r farmakokinetyka leku wpływa na wybór w praktyce klinicznej \\
\hline Instanyl & $\begin{array}{l}\text { Z uwagi na postać leku brak procesu uwalniania, następuje szybkie wchłanianie. Ponadto, dystry- } \\
\text { bucja fentanylu do struktur ośrodkowego układu nerwowego (OUN) następuje nie tylko poprzez } \\
\text { wchłanianie leku do kompartmentu centralnego (układ krążenia), ale także poprzez bezpośrednią } \\
\text { dystrybucję leku do OUN poprzez struktury splotów naczyniowych i struktury układu nerwowego. } \\
\text { Dlatego jest to skuteczne rozwiązanie w sytuacji, kiedy natężenie bólu przebijającego narasta bar- } \\
\text { dzo szybko. Po podaniu donosowym lek charakteryzuje wysoka biodostępność i szybki początek } \\
\text { analgezji (ok. } 5 \text { min). Niestety, bardzo krótki okres działania (< } 1 \text { godz.) ogranicza zastosowanie } \\
\text { leku w dłuższych epizodach BTP lub w przypadku kilku epizodów następujących po sobie w krótkich } \\
\text { odstępach czasowych. Szybki wzrost i spadek maksymalnego stężenia } C_{\max } \text { może zwiększać ryzyko } \\
\text { uzależnienia, zwłaszcza w epizodach BTP narastających wolniej lub trwających dłużej niż czas dzia- } \\
\text { łania leku, kiedy może dochodzić do nieprawidłowego stosowania leku przez pacjenta }\end{array}$ \\
\hline PecFent & $\begin{array}{l}\text { Donosowy roztwór fentanylu na bazie pektyny. Po aplikacji leku dochodzi do interakcji pektyny i } \\
\text { jonów wapnia obecnych w błonie śluzowej nosa w wyniku czego tworzy się żel, który utrzymuje } \\
\text { fentanyl w miejscu podania, uniemożliwiając ściekanie do gardła i połknięcie. Żel pektynowy zapew- } \\
\text { nia szybkie } T_{\text {max }} \text { przekładające się na szybki początek analgezji (5 min) i wydłuża czas wchłaniania } \\
\text { całej dawki fentanylu, co przekłada się na dłuższą stabilizacje } C_{\max } \text { na poziomie terapeutycznym tak, } \\
\text { aby nie dochodziło do szybkich wahań stężenia fentanylu w czasie. Szybki efekt przeciwbólowy } \\
\text { umożliwia stosowanie PecFentu w bólach przebijających o szybkim czasie narastania. Stabilne } C_{\max } \\
\text { na poziomie terapeutycznym przez około } 90 \text { minut zapewnia skuteczność leku także w leczeniu } \\
\text { dłuższych epizodów bólowych lub kilku krótkich epizodów oddzielonych przerwą czasową. Szybki } \\
\text { początek działania, stabilne } C_{\max } \text { na poziomie terapeutycznym i długi okres półtrwania zwiększają } \\
\text { skuteczność leku w różnych rodzajach BTP przez co zmniejszają ryzyko nieprawidłowego zastoso- } \\
\text { wania i nadużywania leku, a w konsekwencji do rozwoju uzależnienia. Dodatkowo, żel pektynowy } \\
\text { uniemożliwia wchłanianie kolejnych dawek fentanylu aplikowanych niezgodnie z charakterystyką } \\
\text { produktu leczniczego, co również znacząco ogranicza ryzyko rozwoju uzależnienia. Z punktu widzenia } \\
\text { farmakokinetycznego wydaje się, że roztwór wodny fentanylu na bazie pektyny jest uniwersalnym } \\
\text { rozwiązaniem w leczeniu większości rodzajów BTP }\end{array}$ \\
\hline Vellofent & $\begin{array}{l}\text { Lek występuje w formie tabletki podawanej podjęzykowo. Po aplikacji tabletka rozpuszcza się przez } \\
\text { okres około } 25 \text { minut. Uwalnianie fentanylu z tabletki może być zaburzone w przypadku kserostomii, } \\
\text { zapalenia śluzówki jamy ustnej i stosowania obwodowo działających leków antycholinergicznych. } \\
\text { Około } 50 \% \text { leku zostaje połknięte i ulega wchłanianiu z przewodu pokarmowego. Lek charaktery- } \\
\text { zuje długi T } \max \text { przy równocześnie średnio długim okresie półtrwania. W związku z niejednorodnym } \\
\text { i rozłożonym w czasie wchłanianiem, możliwy jest nieprzewidywalny wzrost stężenia nieadekwatny } \\
\text { do czasu trwania epizodu bólu przebijającego. Właściwości farmakokinetyczne pozwalają na zasto- } \\
\text { sowanie leku w leczeniu bólu o średnim czasie narastania i dłuższym czasie trwania }\end{array}$ \\
\hline Effentora & $\begin{array}{l}\text { Lek może być podawany zarówno drogą podpoliczkową, jak i podjęzykową. W pierwszej fazie po } \\
\text { podaniu z tabletki uwalniany jest kwas cytrynowy i } \mathrm{CO}_{2} \text { przez co następuje zakwaszenie środowiska } \\
\text { jamy ustnej. Niższe pH sprzyja jonizacji i rozpuszczaniu fentanylu z tabletki. W miarę upływu czasu } \\
\mathrm{CO}_{2} \text { jest eliminowane, co powoduje wzrost pH. Dzięki temu rozpuszczony fentanyl przechodzi w } \\
\text { formę niezjonizowaną i jest dostępny do wchłaniania przez błonę śluzową. Złożony proces uwol- } \\
\text { nienia i wchłaniania fentanylu z tabletki przekłada się na spowolnienie osiągnięcia } \mathrm{C}_{\text {max }} \text { Jedynie } \\
\text { około } 50 \% \text { fentanylu zawarte w tabletce wchłania się przez śluzówkę jamy ustnej, pozostała część } \\
\text { zostaje połknięta i powoli wchłania się z przewodu pokarmowego, podlegając efektowi pierwszego } \\
\text { przejścia, co może powodować nieprzewidywalne wahania stężenia rozłożone w czasie po podaniu } \\
\text { tabletki. Lek charakteryzuje długi okres osiągnięcia stężenia maksymalnego w surowicy i długi okres } \\
\text { półtrwania, co implikuje jego wybór w leczeniu bólu przebijającego o wolnym czasie narastania i } \\
\text { długim czasie trwania }\end{array}$ \\
\hline
\end{tabular}

który zapewni skuteczną analgezję zarówno krótkich (do $60 \mathrm{~min}$ ), jak i dłuższych epizodów BTP. Okres półtrwania odgrywa także istotną rolę w przypadku występowania kilku epizodów BTP dziennie zwłaszcza, kiedy odstępy pomiędzy kolejnymi napadami bólu wynoszą kilka godzin. W takich przypadkach odpowiednio długi okres półtrwania może pozwolić na ograniczenie przyjęcia kolejnej dawki opioidu przez pacjenta.
Ograniczenie konieczności przyjmowania kolejnych dawek leku odgrywa istotną rolę w zmniejszeniu ryzyka rozwoju ewentualnego uzależnienia. Szybki czas osiągnięcia $C_{\max }$ gwarantuje szybki początek działania, jednak jest także czynnikiem zwiększającym ryzyko rozwoju uzależnienia. Efekt ten spotęgowany jest dodatkowo w przypadku szybkiego spadku $C_{\max }$, które może skutkować skróceniem działania terapeutycznego poniżej czasu trwania pojedynczego epizodu 
Tabela 3. Kliniczne kryteria wyboru fentanylu stosowanego w leczeniu bólu przebijającego

\begin{tabular}{ll} 
Charakterystyka bólu przebijającego & Proponowany wybór leku \\
\hline $\begin{array}{l}\text { Bardzo krótki czas narastania bólu przebijającego i krótki } \\
\text { czas trwania }\end{array}$ & $\begin{array}{l}\text { Donosowy roztwór fentanylu lub donosowy roztwór } \\
\text { fentanylu na bazie pektyny }\end{array}$ \\
\hline $\begin{array}{l}\text { Krótki czas narastania bólu przebijającego i dłuższy czas } \\
\text { trwania epizodu bólu przebijającego }\end{array}$ & $\begin{array}{l}\text { Donosowy roztwór fentanylu na bazie pektyny, fentanyl } \\
\text { podjęzykowy }\end{array}$ \\
\hline $\begin{array}{l}\text { Wolny czas narastania bólu przebijającego i przedłużony } \\
\text { okres trwania epizodu bólu }\end{array}$ & $\begin{array}{l}\text { Donosowy roztwór fentanylu na bazie pektyny, fentanyl } \\
\text { podjęzykowy lub podpoliczkowy }\end{array}$ \\
\hline
\end{tabular}

BTP lub serii kilku epizodów następujących szybko po sobie. Może to doprowadzić do sytuacji, w której pacjent zastosuje dodatkową dawkę leku bez zachowania wymaganej przerwy pomiędzy dawkami. Wielokrotna, szybka zmiana $C_{\max }$ stanowi dodatkowy istotny czynnik wystąpienia uzależnienia.

Nieprawidłowa ordynacja leku przez pacjenta może także zwiększać ryzyko uzależnienia w przypadku długiego $\mathrm{T}_{\max }$ które jest nieadekwatne do czasu narastania epizodu BTP. W takich sytuacjach pacjent próbując „poprawić” efekt przeciwbólowy, sięga po kolejną dawką leku, zwiększając $C_{\max }$ ponad „wymiareczkowane" stężenie terapeutyczne leku. Wzrost stężenia opioidu nieadekwatny do zapotrzebowania wynikającego z epizodów bólu przebijającego może także wystąpić w przypadku połknięcia części fentanylu zawartego w produktach przezśluzówkowych. Wchłanianie z przewodu pokarmowego jest związane z efektem pierwszego przejścia, co może spowodować nieprzewidywalne skoki stężenia w stosunku do stężenia uzyskanego drogą przezśluzówkową. W konsekwencji może wystąpić nieadekwatny do zapotrzebowania wzrost stężenia opioidu. Ze względu na różne formulacje fentanylu przeznaczonego do leczenia BTP, w wyborze optymalnej terapii należy uwzględniać także czynniki bezpośrednio wpływające na możliwe drogi podania. Kserostomia występuje u 78-82\% chorych na nowotwory, niedoczynność gruczołów ślinowych (u 82-83\% pacjentów) i zapalenia śluzówki jamy ustnej u 20-40\% chorych poddawanych chemioterapii mogą uniemożliwiać wybór drogi podjęzykowej lub podpoliczkowej. Z kolei krwawienie z nosa może zaburzać wchłanianie z roztworów donosowych. W tabeli 1 przedstawiono parametry farmakokinetyczne poszczególnych leków zawierających fentanyl dostępnych na polskim rynku.

Z praktycznego punktu widzenia dla wyboru analgetyku odpowiedniego do charakterystyki BTP istotny jest nie tylko początek działania, ale także stabilność stężenia leku w stanie stacjonarnym i okres półtr- wania [1, 2, 7-9]. Częstym błędem jest stosowanie buprenorfiny drogą podjęzykową w leczeniu bólu przebijającego. Brak skuteczności tej postaci leku jest związany z czasem, po jakim od podania leku osiąga stężenie maksymalne $\left(C_{\max }\right)$. Parametr ten $\mathrm{w}$ istotny sposób decyduje o początku skutecznej analgezji, a dla buprenorfiny podawanej drogą podjęzykową wynosi 90 minut. Całkowity efekt przeciwbólowy jest zależny od całkowitej ekspozycji na lek, przez którą rozumiane jest pole powierzchni pod krzywą zmian stężenia w czasie. W tabeli 2 zebrano informacje będące pomocne w wyborze odpowiedniego leku w zależności od charakterystyki bólu przebijającego.

W tabeli 3 przedstawiono propozycje stosowania poszczególnych postaci szybko działającego fentanylu na podstawie charakterystyki bólu przebijającego.

\section{Podsumowanie}

Wybór leku w terapii bólu przebijającego powinien podlegać indywidualizacji. Znajomość profilu PK/PD pozwala na optymalny wybór skutecznego i bezpiecznego produktu leczniczego [1, 2, 9]. Warto pamiętać, że fentanyl stosowany w leczeniu bólu przebijającego można łączyć z innymi opioidami, także z buprenorfiną, która do dawki pułapowej wykazuje charakterystykę agonisty receptora mu. Nie zalecane jest jedynie łączenie fentanylu z nalbufiną $[1,2,5,8,9]$. Ponieważ BTP może wykazywać inny patomechanizm niż ból podstawowy, w praktyce klinicznej dawka opioidu stosowana w leczeniu BTP raczej nie stanowi odpowiedniego ułamka (odsetka) dawki stosowanej w leczeniu bólu podstawowego. Złożoność zjawisk, które prowadzą do wystąpienia epizodu bólu przebijającego, raczej wykluczają takie proste przeliczenia. Kluczowa pozostaje dokładna ocena kliniczna bólu w kontekście innych objawów występujących u pacjenta, sytuacji psychologicznej, socjalnej i duchowej [2-5]. 